\title{
Borrowing of phonological rules: case studies from Romani, Armenian and Yiddish and some general reflections
}

\begin{abstract}
Borrowing of phonological rules is a topic that has received scant attention outside the domain of language learning. If transferring of L1 phonological rules in L2 utterances is a banal phenomenon, more interesting is the case in which phonological rules borrowing affects a still well preserved minority language, innovating its syntagmatic phonology. In these cases the intra-communitarian language of a minority community adopts, partially or totally, the phonological rules of the inter-communitarian language, i.e. of the language of the majority community. The article discusses several examples of phonological rules borrowing, notably two Italo-Romance phonological rules borrowed in Abruzzian Romani, Turkic vowel harmony in the Armenian dialect of Karchevan and Belarus akanie in Belarus Yiddish. After discussing the rules and the way they have been imported, the article proposes some general reflections about the structural and sociolinguistic background of the phenomenon.

Keywords: phonological rules, linguistic borrowing, Romani, Armenian, Yiddish, language contact
\end{abstract}

In the studies concerning the outcomes of language contact, the borrowing of syntagmatic phonology, that is the borrowing of phonological rules, seems to be a rather peripheral topic. In the perspective assumed in this paper borrowing of phonological consists in the imitation of the phonological rules of another language outside the process of language learning. In fact the presence of L1 phonological rules in utterances in L2 is a banal phenomenon, while those cases in which phonological rules are transferred from a co-territorial language on the first language of a community are much more uncommon and intriguing. As every phenomenon of innovation borrowing of phonological rules represents a chapter of language change, and therefore a topic to be inscribed in the domain of historical linguistics; however, the number of cases described so far is relatively scant (Campbell 1976, 1998: 74; Thomason 2001: 87, 2006; Matras 2009: 229-230; Savoia 2008: 43-46) and it is quite probable that a broader collection of empirical data can enable some general considerations about the inner working of the transfer of phonological rules from a language to another one in a plurlingual repertoire. The cases we will deal with in this article come from Abruzzian Romani (Abruzzo and Molise, Middle Italy), from the Armenian dialect of Karchevan (Republic of Armenian, Syunik Province) and, although very concisely, from Yiddish as spoken in Belarus. In all these cases new phonological rules, once unknown to Romani, Armenian and Yiddish, have been acquired via contact from other languages and are now applied to inherited lexicon.

\subsection{Abruzzian Romani between conservation and innovation}

Abruzzian Romani is the Indo-Aryan language that has been spoken in Italy by the Roma communities of Abruzzo, Molise and the surrounding areas form the $16^{\text {th }}$ century circa. In these centuries of permanence in Middle Italy Abruzzian Romani speakers have developed 
a long and deep history of bilingualism, with a linguistic repertoire consisting mainly of Romani (Indo-Aryan) and Abruzzese (Italo-Romance). At the present time, however, a significant number of Abruzzian Roma can be considered trilingual, since the last generations have acquired also a more or less ample knowledge of the regional variety of Italian spoken in Abruzzo and Molise. Up to present day, Abruzzian Romani preserves its role of intra-communitarian and identity language very well, while the function of inter-communitarian code is obviously fulfilled by the Italo-Romance branch(es) of the repertoire, especially by Abruzzese. The vitality of Abruzzian Romani has been repeatedly highlighted, especially in comparison with the clear condition of decadence of other Romani varieties, closely related to it, spoken in Southern Italy, such as Calabrian Romani (cfr. e g. Soravia 1978: 4; 2009: 75). Abruzzian Romani still counts some thousands of native speakers and the sources available for its study are not few, however many structural and lexical aspects of this Romani variety remain almost unexplored. In this contribution I will use three different sources on Abruzzian Romani:

1) the very abundant data collected by Ugo Pellis in 1932 in Annunziata di Giulianova (close to Teramo, Abruzzo), point 603 of ALI (Atlante Linguistico Italiano). Ugo Pellis data consist of a rich collection of lexical items and of some sentences labelled as "translations" (Pellis 1936).

2) the documentation (oral texts and lexical list) published by Morelli-Soravia 1998

3) the questionnaire of the Romani Morpho-Syntax Database (RMS) recorded by means of two different informants in Campobasso, Molise (http://romani.humanities.manchester. ac.uk/rms/).

A noteworthy characteristic of Abruzzian Romani is represented by the high degree of retention of Indo-Aryan features extensively shared among the Romani dialects and therefore ascribed to Early Romani: especially phonological units and the lexical layers common to all Romani varieties have undergone very slight innovations, which are also scant in number. Also the majority of morphological units and processes are still preserved, except for nominal declension, which has been lost. For these reasons Abruzzian Romani can be considered a rather conservative dialect, if compared with other Romani dialects spoken in Europe. In the opinion of Yaron Matras Abruzzian Romani, Dolenjska Romani (spoken in Slovenia, Croatia and Italy), as well as British, Iberian and Epirotic Romani can be considered as a "series of peripheral dialects" forming "relic areas" (Matras 2005: §7) in the classification of Romani dialects. Of course Abruzzian Romani also shows a set of innovations which characterize it in comparison with other Romani dialects; a significant amount of these innovations concerns phonological rules, which actually correspond to those of Abruzzese dialects spoken in Abruzzo and Molise and in all probability have been borrowed from them in a century long history of contact. The outcome is rather unusual: an Indo-Aryan language, which preserves the majority of its original features, but which shows strong innovations in the phonological rules, which have been massively imported by Italo-Romance (Abruzzese) co-territorial varieties. In the next pages the following abbreviations will be used to refer to the different sources for Abruzzian Romani:

Pe $=$ Pellis 1936 (tr. = translations)

RMS 7 = http://romani.humanities.manchester.ac.uk/rms/ female informant (IT-007 Molise)

ARms $=$ Morelli-Soravia 1998

Other Romani dialects: PS = Piedmontese Sinti, LS = Lombard Sinti, CR = Calabrian Romani (as spoken in Reggio Calabria), KL = Kalderashitska, WR = Welsh Romani. 


\subsection{Two phonological rules borrowed from Abruzzese}

Among the phonological rules that Abruzzian Romani has probably borrowed from Abruzzese (Scala 2018), two cases will be discussed, notably the propagation of $/ \mathrm{u} /$ and the devoicing of $/ \mathrm{d} /$ after stressed vowel. Both rules are of some significance for the history of Abruzzian Romani and, more in general, for phonological contact theory as well. The model for these innovations is represented by rules which are active and widespread in Abruzzese, but which are totally unknown to Romani varieties other than Abruzzian Romani. The source and the direction of the borrowing is therefore clear and sure. Moreover, the two borrowed rules which will be discussed seem to be cross-linguistically rather uncommon, so that a polygenetic and independent origin of these rules in Abruzzese (and in other Southern ItaloRomance dialects) and in Abruzzian Romani has to be excluded as quite improbable.

\subsubsection{Insertion of non-etymological $[\mathrm{w}] /[\mathrm{w}]$ as result of $/ \mathrm{u} /$ propagation}

The propagation of $/ \mathrm{u} /$ is a phenomenon which can be described as the insertion of a nonetymological $[\mathrm{w}]$, sometimes to be interpreted as the second part of a complex articulation $\left[\ldots{ }^{w}\right]$, after the onset of a syllable, when the preceding syllable, within the phonological word (i.e. also a syllable of a previous proclitic word), contains /u/ (cfr. Tuttle 1985, who provides to the phenomenon the very personal label of "assimilazione permansiva"). Such a process is well documented and still widely active in many Southern Italo-Romance dialects (Savoia 1987; Rizzi-Savoia 1993; Schirru 2008 and 2012-2013), but outside these dialects the only similar process of propagation which has been signaled so far appears in Birom (Tuttle 1985: 29), a language spoken in Nigeria (classification: Niger-Kordofanian group, Niger-Congo sub-group, Benue-Congo branch, cfr. Turchetta 2008: 492).

The process can be exemplified by the Southern Italo-Romance type ['ka:nə] “dog” vs [lu 'kwa:nə] "the dog": the insertion of a non-etymological [w] in [lu 'kwa:nə] depends on the presence of $\mathrm{a} / \mathrm{u} /$ in the preceding syllable within the phonological word; as for Abruzzian Romani the $/ \mathrm{u} /$ propagation is well attested to in all the available sources. The examples listed below allow us to individuate the underlying phonological rule (cfr. also Scala 2015 and 2018):

1. [u 'kwaftə] “the stick” (Pe 543), but [ni 'kaftə] “a stick” (Pe 3077), cfr. conservative Romani kašt (OIA kāṣtha "piece of wood")

2. [u 'kwe:rə] "the house" (Pe 1497), but ['ke:rə] "house", conservative Romani kher (OIA grha "house", with some phonetic difficulties, Pkr. ghara)

3. [u 'gwa:tə] "the shirt” (Pe 634), but [ni 'ga:tə] "a shirt”, conservative Romani gad (OIA gātrā m. "limb, member of body" and gātrikā "girdle" both phonetically and/or semantically problematic, Hi. gātī "rural clothing")

4. [Jun'gweskərə] "parsley” (Pe 1969), conservative Romani sung-/šung- (OIA śinghati "to smell”, Pkr. sumghai “id.”)

5. [tu 'xwa:sə] “you (sg.) eat” (Pe tr. 2), but [mə 'xa:və] "I eat”, (Pe tr. 1) conservative Romani xa- "to eat" (OIA khādati "to eat", Pkr. khāaï "id.")

6. [u 'xwe:rə] 'the donkey' (Pe 1619), but ['xe:rə] 'donkey' conservative Romani xer (OIA khara "donkey")

7. [so kwin'ne:n a'iddzə] 'what did you buy yesterday?' (RMS 7 550), but [kin'ne:nə] 'you (pl.) bought', conservative Romani kin- "to buy" (OIA krīnāti "to buy")

8. [ni kafu'kwo] “a piece of money” (RMS 7 709), perhaps a wordplay based on Abruzzese sórda "money" and "deaf”, conservative Romani kašukó "deaf” (OIA karṇa “ear” + śușka “dry”) 
And yet [u kwarmu'so] "the rat" (Pe 854), but [ni karmu'so] "a rat” (Pe 853); [u kwe'ra:lə] "the cheese" (Pe 881), but ARms [ki'ra:lə], CR [ke'ra:lə] “cheese”; [u ddzu'kwe:lə] "the dog” (Pe 2978), but ARms CR [dzu'ke:lə] “dog”; [u kwa'ro] "the thorn” (Pe 3085), but RAms [ka'ro] "thorn"; [adu'kwammə] "it hurts me" (Pe tr. 53) but ARms [duk'kammə] "id.”; [dzungwa'lo] "ugly" (Pe 3336), but ARms CR [dzunga'lo] “id."; [u xwab'be] "the "food” (RMS 7 787), but CR [xa'be] "food"; [u xwa'ro] "the dagger" (Pe 2623), but LS ['xaro] "id." etc.

In Abruzzian Romani the propagation of $/ \mathrm{u} /$ targets syllables with a velar stop or a velar fricative in the onset and all vowels except $/ \mathrm{u} /$ in the nucleus. As the examples clearly show, propagation is possible both with intra-lexical trigger (cfr. [Jun'gweskərə] "parsley", [dzungwa'lo] "ugly" etc.) and extra-lexical trigger (cfr. [u 'kwe:rə] "the house”, [u 'gwa:tə] "the shirt" etc.), within the phonological word. The phonetic outcomes [kw], [gw] and [xw] can be perhaps better interpreted as rounded velar sounds $\left[\mathrm{k}^{\mathrm{w}}\right],\left[\mathrm{g}^{\mathrm{w}}\right]$ and $\left[\mathrm{x}^{\mathrm{w}}\right]$, that is as a single phonic unit, because in Abruzzian Romani [w] does not belong to the phonemic inventory and, as phonetic unit, it represents only a non-mandatory allophonic realization of /v/, cfr. $u$ vast "the hand" realized both [u vast] and [u wast]. Starting from this consideration and from the examples listed above, the rule operating behind propagation in Abruzzian Romani can be represented as in table 1 :

Table 1. /u/ propagation rule in Abruzzian Romani

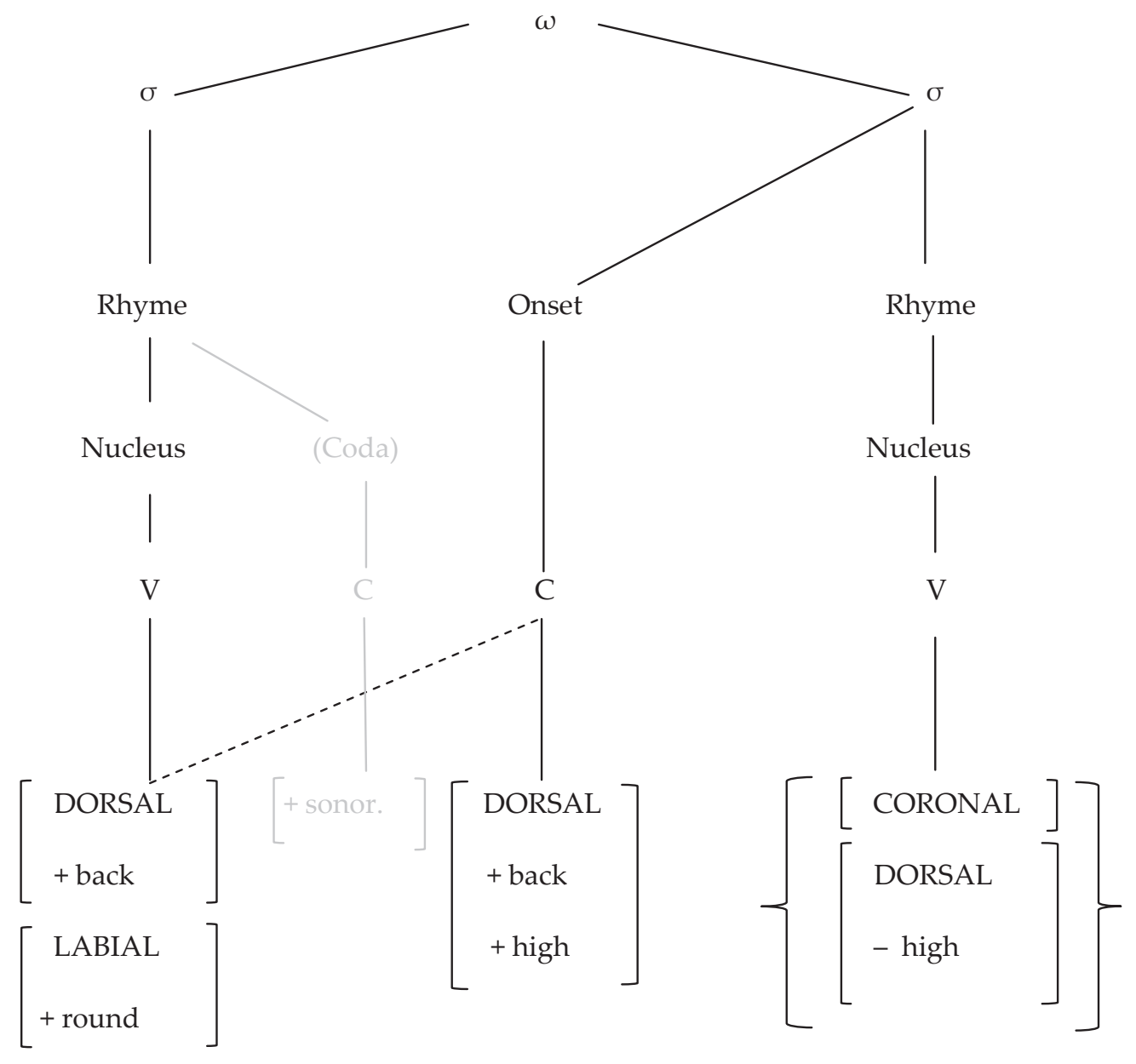


As said above, the rule is unknown to other Romani dialects, and it is clearly borrowed from Abruzzese. Even Calabrian Romani, a sub-branch of Southern-Italian Romani (Soravia 1978), historically very close to Abruzzian Romani and probably representing a mere subbranch of it, does not know such a rule. In Abruzzian Romani however trigger vowels and target syllables are slightly different respect to Abruzzese. The rule, which applies to Abruzzese and Molisean dialects (Schirru 2008: 294), is described in table 2:

Table 2. /u/ propagation rule in Abruzzese

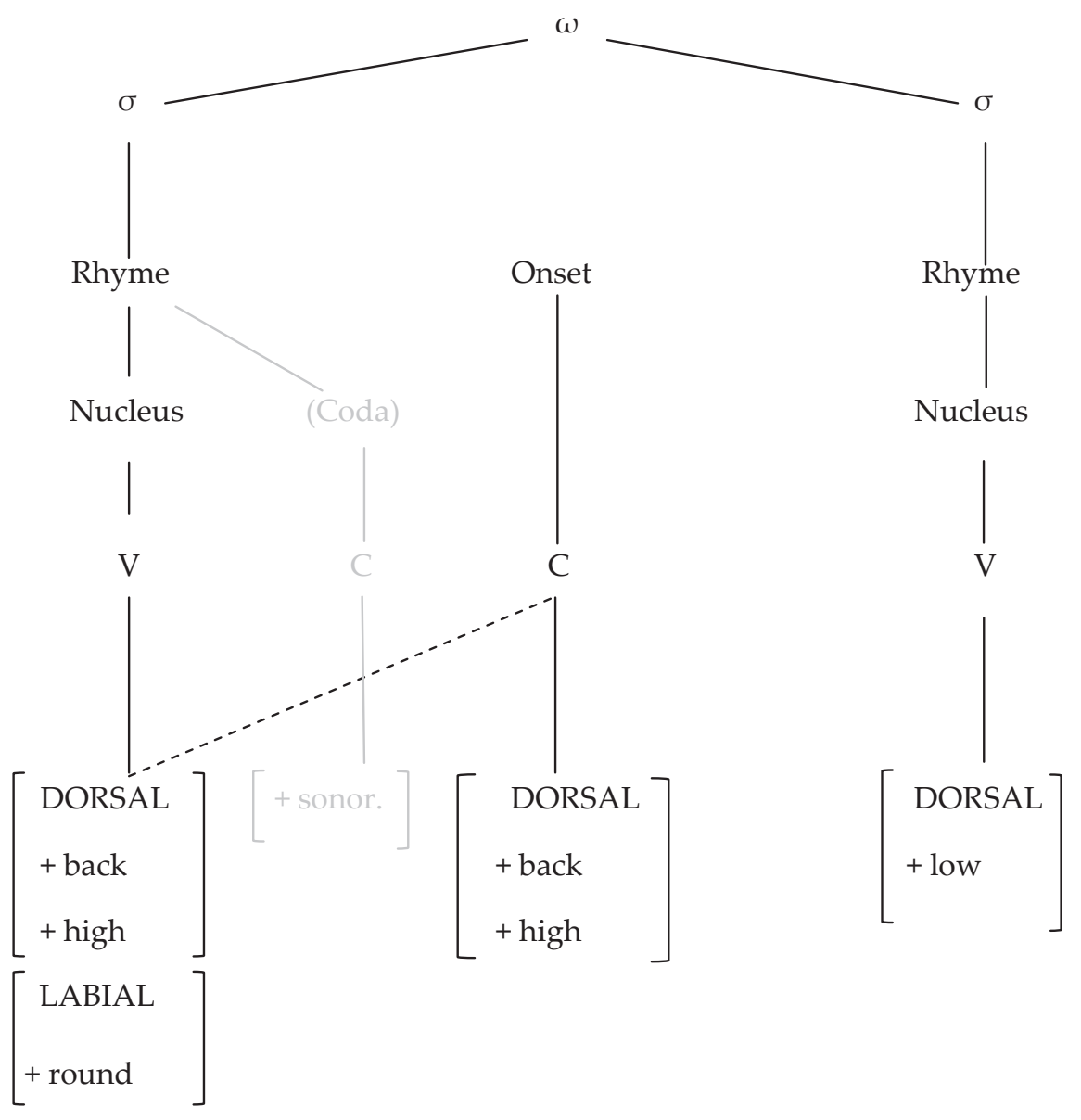

In Abruzzese the only trigger is $/ \mathrm{u} /$ and its propagation affects syllables beginning with a velar stop and having /a/ in the nucleus. A different set of triggers that includes also /i/ (propagated as $[\mathrm{j}] /[\mathrm{C}]$ ) and a richer set of vowel targets can be found elsewhere in some other Southern Italio-Romance dialects and we do not know whether such a more complex situation was present in the past in Abruzzese too. In Abruzzian Romani propagation is triggered by / $\mathrm{u} /$ and /o/ as well (cfr. n. 7), i.e. by all [+ back] and [+round] vowels and targets also syllables whose nucleus contains /i/ (cfr. n. 7), /e/ (cfr. nn. 2, 4 and 6) and /o/ (cfr. n. 8). A very important fact in this process of rule borrowing is represented by the difference between the set of velar obstruents in the phonological inventory of the model and replica languages. The phonological inventory of Abruzzian Romani includes a fricative velar phoneme / $/$ /, unknown to Abruzzese, which is targeted by the propagation rule (cfr. nn. 5 and 6). This situation is noteworthy: the rule has been borrowed with reference to the features acting in the allophonic process and not with direct reference to the phonological units of Abruzzese; if so, we would 
not expect that the rule can target a phoneme unknown to Abruzzese, such as $/ x /$ is. The borrowed rule not only affects a velar phoneme absent in the Abruzzese phonemic inventory, but also occurs before vowels, such as /e/ and /i/, which exist in Abruzzese, but are extremely rare after $/ \mathrm{k} /$ and $/ \mathrm{g} /$ on account of the Romance palatalization of velar stops before front vowels. In the dialects of Abruzzo and Molise the Romance palatalization has extensively changed the Latin sequence CE, CI, GE, GI in / $\mathrm{te} /$, / $/ \mathrm{fi} /$, /dze/, /dzil, so that words beginning with $/ \mathrm{ki} /$, / ke/, /ge/, /gi/ are particularly scant and in the majority of cases they are pronouns in which the trigger $/ \mathrm{u} /$ is not present or not possible (this is the case with the article $u$, which very often acts as propagation trigger before nouns, but which cannot be placed before pronouns). The extension of the rule to syllables containing /o/ in the nucleus completes the set of targets in Abruzzian Romani, excluding only the nucleus /u/. In fact the rule works with all triggers having the features [+back] and [+round] and affects all syllables whose onset contains an obstruent [+back] and [+high], including /x/, a phoneme, as said before, unknown to Abruzzese. As for the nucleus of the targeted syllable, the propagation rule has just one restriction: it does not apply if the vowel of the nucleus is $/ \mathrm{u} /$ that is a vowel having the same features [+back], [+high] and [+round] of the outcome $[w] /\left[\ldots{ }^{w}\right]$. In this process too loanwords from Abruzzese do not seem to play any significant role, because they could not offer a model for the form assumed by the rule in Abruzzian Romani, both in terms of targets and of triggers. The imitation of Abruzzese / $\mathrm{u} /$ propagation merely represents an application of an Abruzzese phonological rule to the Abruzzian Romani phonemic inventory via phonological features and not via phonological units. The extension of the rule to targets and triggers which do not operate in Abruzzese is very clear in this sense and is likely to depend on the transfer of a rule on the lexicon of Abruzzian Romani and not on a rule extrapolation from the Abruzzese lexical items affected by propagation. Such a transfer can be possible only to bilingual speakers who have unified and generalized a phonological rule across the two codes of their bilingual competence.

\subsubsection{Devoicing of /d/ after stressed vowel}

Devoicing of /d/ regularly happens in Abruzzian Romani when this phoneme occurs after a stressed vowel. Examples such as ['tu:tə] "milk" (Pe tr. 38 and 43), ['da:tə] "father" (Pe 14, tr. 48 and 49), ['ga:tə] “shirt” (Pe 634 and 635), ['du:tə] "light” (Pe 806 and 1507), ['vo:tərə] "bed" (Pe 833 and 1064), ['kli:tə] "key" (Pe 1087) are very eloquent. All these words present a non-etymological [ $\mathrm{t}$ ], as shown by the comparison with the equivalent words in other Romani dialects: cfr. KL [thud] "milk", PS [dad] "father", [gad] "shirt", [dud] "light", ['vodro] "bed" and LS ['klidi] "key". In the light of these data there is no doubt that [t] has to be considered as secondary and limited, in the whole Romani dialect landscape, only to Abruzzian Romani. Interestingly devoicing of $/ \mathrm{d} /$ after stressed vowel is well documented in co-territorial Abruzzese dialects too. The phenomenon is clearly observable in cases such as ['kru:tə] "raw" < Lat. CRŪDU(M), ['pe:tə] “foot” < Lat. < PĔDE(M), ['ri:tə] “to laugh” < Lat. *RĪDĔRE (Cl. Lat. RĪDĒRE), ['ni:tə] "nest" < NİDU(M) and in many other examples (Giammarco 1960: 47-48; Rohlfs 1966-1969: § 216; Bigalke 1996: 19-20). When the stress is on the vowel which follows /d/ the underlying phoneme surface as voiced in the most of Abruzzese dialects, cfr. e.g. in Pescara ['no:tə] "knot" < Lat. NŌDU(M) vs [nu'du:sə] "knobby" < Lat. NŌDŌSU(M), in Introdaqua (Province of L'Aquila) ['kre:te] "I believe" < Lat. CRĒDO vs [kre'du:tə] "believed" < Lat. *CRĒDŪTU(M), in Penne (province of Pescara) ['ve:tə] “you (sing.) see” < Lat. VĬDĒS vs [ve'do] "to see” < Lat. VILEERE etc. The presence of an alternation between the devoiced allophone after stressed vowel and the voiced one after unstressed vowel and especially in pre-tonic position implies 
the existence of a phonological rule still operating in synchrony and not a phonetic change already achieved and penetrated in the underlying lexical representation. Only in few Abruzzese dialects the devoiced variant has been lexicalized and the rule has ceased to operate. Some years ago Leonardo Savoia has proposed an interesting explanation for a very akin phenomenon observable in the dialect of Andria (Northern Puglia). Savoia explains the loss of sonority after stressed syllable as an extension to the subsequent /d/ of the feature [+ stiff vocal folds]. This feature would depend on the high tone of the stressed vowel (Savoia 2014: 249-257). If vocal folds remain stiff during the realization of $/ \mathrm{d} /$, they do not allow the activation of the laryngeal mechanism. The consequence is a loss of sonority in the consonant.

Taking Abruzzese ['kru:tə] < Lat. CRŪDU(M) "raw" as an example, the rule can be represented as in table 3:

Table 3. /d/ devoicing rule in Abruzzese

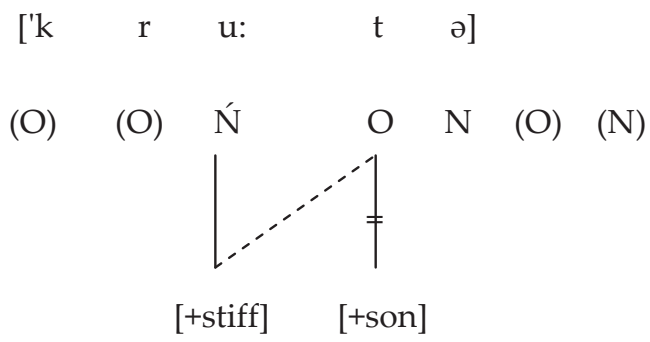

In Abruzzian Romani (see table 4) the rule is mandatory, cfr. e. g. the form which surfaces as ['tu:tə] "milk". The word in Early Romani was thud as confirmed by the most conservative variety of Romani (cfr. KL [thd]) and by the etymology (cfr. OIA dugdha "milked, milk", Pkr. duddha; the Romani form supposes aspiration metathesis *dhudda):

Table 4. /d/ devoicing rule in Abruzzian Romani

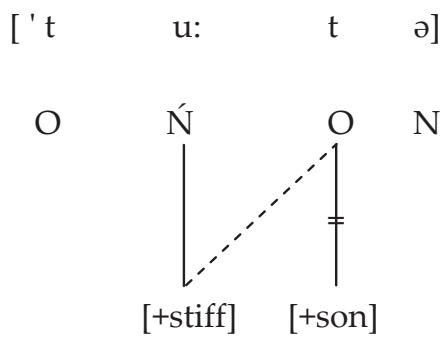

This rule cannot have been extrapolated by Abruzzian Romani speakers from Abruzzese loanwords. A sequence $V ́+[t]$ in Abruzzese words would have represented a model well known to Romani and would have been reproduced without any difficulty and, above all, without introducing any new phonological rule. Indeed, in Abruzzian Romani there are many words, belonging to pre-Romance lexical layers, in which the sequence $V ́+[t]$ is etymological, cfr. [b'bu:tə] "much” (OIA bahutva), ['ka:tə] "scissors" (Pkr. kattiya), ['fu:tə] "vinegar” (OIA śukta), ['dze:tə] “oil” (Arm. jêt'). Only synchronic alternations between [d] and [t], caused by the shift of stress position in Abruzzese verbal paradigms and nominal derivation, can have offered a model for this rule of devoicing, which has been transferred to Abruzzian Romani. Alternations between [t] and [d]/[dd], like in [fi'ri:tə] "window", pl. [fərid'dja] (from Gr. Ovoísı, cfr. Scala 2006-2007: 49) testify that the rule /d/ $\rightarrow$ [t] / V́ is fully active in Abruzzian Romani, irrespective of the real presence of a high tone in the stressed syllable of the replica- 
language. A rule based on a phonetic feature, in this case the feature [+ stiff vocal folds], may be extended to another language by bilingual speakers, becoming a mere distributional rule. In the case of Abruzzian Romani, devoicing of /d/ after stressed syllable preserves the relation between input and output that we find in Abruzzese, but does not necessarily preserve the phonetic motivation underlying to the rule in the model language.

\subsection{The borrowing of epenthetic vowel harmony in the Armenian dialect of Karchevan}

The Armenian dialect of Karchevan (Republic of Armenian, Syunik Province; for a description of the dialect cfr. Mowradyan 1960) presents a system of vowel harmony which we may assume as imported by Azerbaijanian, a Turkic variety with which Armenian speakers of Karchevan have been in contact for centuries. Alternations based on vowel harmony are unknown to Proto-Indo-European, to Old Armenian and to the majority of Armenian dialects, but in some minor dialects vowel harmony was and is well rooted. The phenomenon shows a scattered geographical distribution - from Cilicia (e. g. Marash and Zeythun cfr. respectively Galustean 1934 and Ačaryan 2003: 144-146) to Northern Iran (e.g. Maragha, cfr. Adjarian 1929: 81-82 and Łaribyan 1953: 361) - which suggests to consider this phonological feature as a polygenetic innovation acquired via contact. After all, in this area, Armenian is not the only language showing such an innovation: vowel harmony systems can be found also in some varieties of Greek spoken in Anatolia (Dawkins 1916: 67-68; Thomason-Kaufman 1988: 218), in some Iranian dialects such as Tati (Yar-Shater 1969: 54-55) and in some Lezghian dialects (Johanson 2006), among them Budukh (Alekseev 1994: 263), Kryts (Saadiev 1994: 410) and Khinalug (Kibrik 1994: 373), all in contact with Azerbaijanian. Also the contact between some Eastern Armenian dialects and Azerbaijanian has been very intense. It could be useful to remind that at the begin of the nineteenth century only $17.6 \%$ of the inhabitants of Eastern Armenia was Armenian, the remainder of the population being composed by Turks and Kurds (Bournoutian 1996: 78-79).

As shown by Bert Vaux, Armenian dialects display three different types of vowel harmony: root harmony (i.e. harmony of the lexical morpheme), affixes-harmony, and epenthetic vowel harmony (Vaux 1998: 151). These different domains can be connected as follows:

1) affixes-harmony implies root-harmony (cfr. the dialects of Agulis, Karchevan, Maragha, Meghri, Shamaxi, Tigranakert, Xoy). Here the domain is the morpho-syntactic word.

2) epenthetic vowel harmony, a post-lexical phenomenon, usually implies the harmony in the morpho-syntactic word (Maragha, Karchevan, Shamaxi), so the domain becomes the phonological word. The only exception is represented by the dialect of Marash with root-harmony and epenthetic vowel harmony, but without affixesharmony.

These relations between the domains seem to indicate that the most prototypical, although not exclusive, target of the harmony is the morpho-syntactic word or the phonological word.

In Karchevan's dialect vowel harmony affects the lexical morpheme, the affixes and the epenthetic vowel. This latter, that in the majority of Armenian dialects surfaces as [ə] shows different colours in the dialect of Karchevan, according with the features of the preceding vowel. In Azerbaijanian we find the same phenomenon, but the outcomes of these two vowel harmonies (the Turkic one and that of the Armenian dialect of Karchevan) are different. 


\subsection{Phonological inventories and rule borrowing}

In Azerbaijanian epenthetic vowel surfaces as following:

$$
\begin{aligned}
& \text { after /o, u/ } \rightarrow \mathrm{u} \text { [son] “end" [sonun'dzu] "last”; [o'tuz] '30' [otuzun'dzu] “30"th" }
\end{aligned}
$$

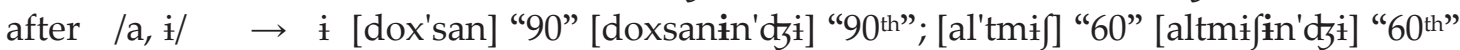

$$
\begin{aligned}
& \text { after } / \varnothing, y / \rightarrow y \text { [dørd] “4” [dørdyn'dzy] “4th"; [yt] “3” [yt fyn'dzy] “3"th" } \\
& \text { after / æ, e, i/ } \rightarrow \text { i [sæ'ksæn] “80" [sæksænin'dzi] "80th"; [bef] “5” [befin'dzi] “5th"; } \\
& \text { [bir] "1" [birin'dzi] “1st” }
\end{aligned}
$$

As it can be observed Azerbaijanian epenthetic vowels are pre-specified for the feature [+high] and receive the specifications [ $\alpha$ round] and [ $\alpha$ back] of the previous vowel, according to a pattern similar to what we found in other Turkic varieties and that we can represent as in table 5:

Table 5. Epenthetic vowel harmony in Azerbaijanian<smiles>CCCCCCCCCCCCC</smiles>

(C) $\mathrm{VC}(\mathrm{C}) \mathrm{V}_{\mathrm{e}} \quad \mathrm{V}_{\mathrm{e}}[+$ high $]=/ \mathrm{y} /$<smiles>CCCCCCCCCCCCCCCCCC</smiles>

(C) $\mathrm{VC}(\mathrm{C}) \mathrm{V}_{\mathrm{e}} \quad \mathrm{V}_{\mathrm{e}}[+$ high $]=/ \mathrm{i} /$<smiles>CCCCCCCCCCCCCCCCCCC</smiles>

(C) $\mathrm{VC}(\mathrm{C}) \mathrm{V}_{\mathrm{e}} \quad \mathrm{V}_{\mathrm{e}}[+$ high $]=/ \mathrm{i} /$<smiles>CCCCCCCCCCCCCCCCCCC</smiles>

(C) $\mathrm{VC}(\mathrm{C}) \mathrm{V}_{\mathrm{e}} \quad \mathrm{V}_{\mathrm{e}}[+$ high $]=/ \mathrm{u} /$

This harmony is based on the following vowel inventory (Khalilzadeh 2013):

\begin{tabular}{c|c|c|c|c}
\hline \multirow{2}{*}{} & \multicolumn{2}{|c|}{$[-$ back $]$} & \multicolumn{2}{c}{$[+$ back $]$} \\
\cline { 2 - 5 } & {$[-$ round $]$} & {$[+$ round $]$} & {$[-$ round $]$} & {$[+$ round $]$} \\
\hline$[$ +high $]$ & $\mathrm{i}$ & $\mathrm{y}$ & $\dot{\mathrm{i}}$ & $\mathrm{u}$ \\
\hline$[$-high $]$ & $\mathrm{e}, \mathrm{a}$ & $\varnothing$ & $\mathrm{a}$ & $\mathrm{o}$ \\
\hline
\end{tabular}

In the Armenian dialect of Karchevan (Vaux 1998: 165-171) vowel harmony, borrowed by contact with Azerbaijanian, operates in the domain of the phonological word. The phonological system of the dialect of Karchevan is however different from that of Azerbaijanian and could be represented as follows (Vaux 1998: 166):

\begin{tabular}{c|c|c|c|c}
\hline \multirow{2}{*}{} & \multicolumn{2}{|c|}{$[$ - back] } & \multicolumn{2}{c}{ [+ back] } \\
\cline { 2 - 5 } & [- round] & [+ round] & [- round] & [+ round] \\
\hline [+high] & $\mathrm{i}$ & $\mathrm{y}$ & & $\mathrm{u}$ \\
\hline$[$-high] & $\mathrm{e}, æ,(\varepsilon)$ & $\varnothing$ & $\mathrm{a}$ & $\mathrm{o}$ \\
\hline
\end{tabular}


Limiting the analysis to epenthetic vowels, it is possible to infer the vowel harmony rules acting in this domain for example by observing the allomorphs of definite article. Definite article in Armenian varieties is postposed since the time of Classical Armenian (CA). In Modern Armenian varieties article's underlying form can be considered /-n/ and it usually surfaces as [-n] in two cases: after vowel (1), after consonant in a word that precedes another word beginning in a vowel, more explicitly in the context $-\mathrm{C} \_\# \mathrm{~V}$ - (2). After final consonant before pause (3) or before a word beginning in consonant (4) the article surfaces as $\left[-\mathrm{V}_{\mathrm{e}}\right]$, phonetically represented by [-ə], because of a rule that deletes word-final /-n/ in unstressed syllable (Vaux 1998: 257258). This distribution rule operates both in Standard Western Armenian (SWA) and in Standard Eastern Armenian (SEA). In CA allomorphs were partially different: the outcome [-n] had the same distribution than in modern varieties, while the contexts (3) and (4) triggered a surface form [-ən] with no deletion of /-n/. In modern standard varieties article's surface form in (3) is [-ə] without exceptions, but the surface outcome becomes more complex in those dialects whose vowels are sensitive to vowel harmony. Further confirmations of the vowel harmony process that affects epenthetic vowels in harmonic Armenian dialects can come also from words in which a consonant cluster requires the insertion of an epenthetic post-lexical vowel. This post-lexical vowel is regularly [ə] in CA, SEA and SWA, but, like in the case of the article, it receives different colours in harmonic dialects. Karchevan's dialect is a good example of dialect in which vowel harmony affects epenthetic vowels, that regularly surface in the following way:

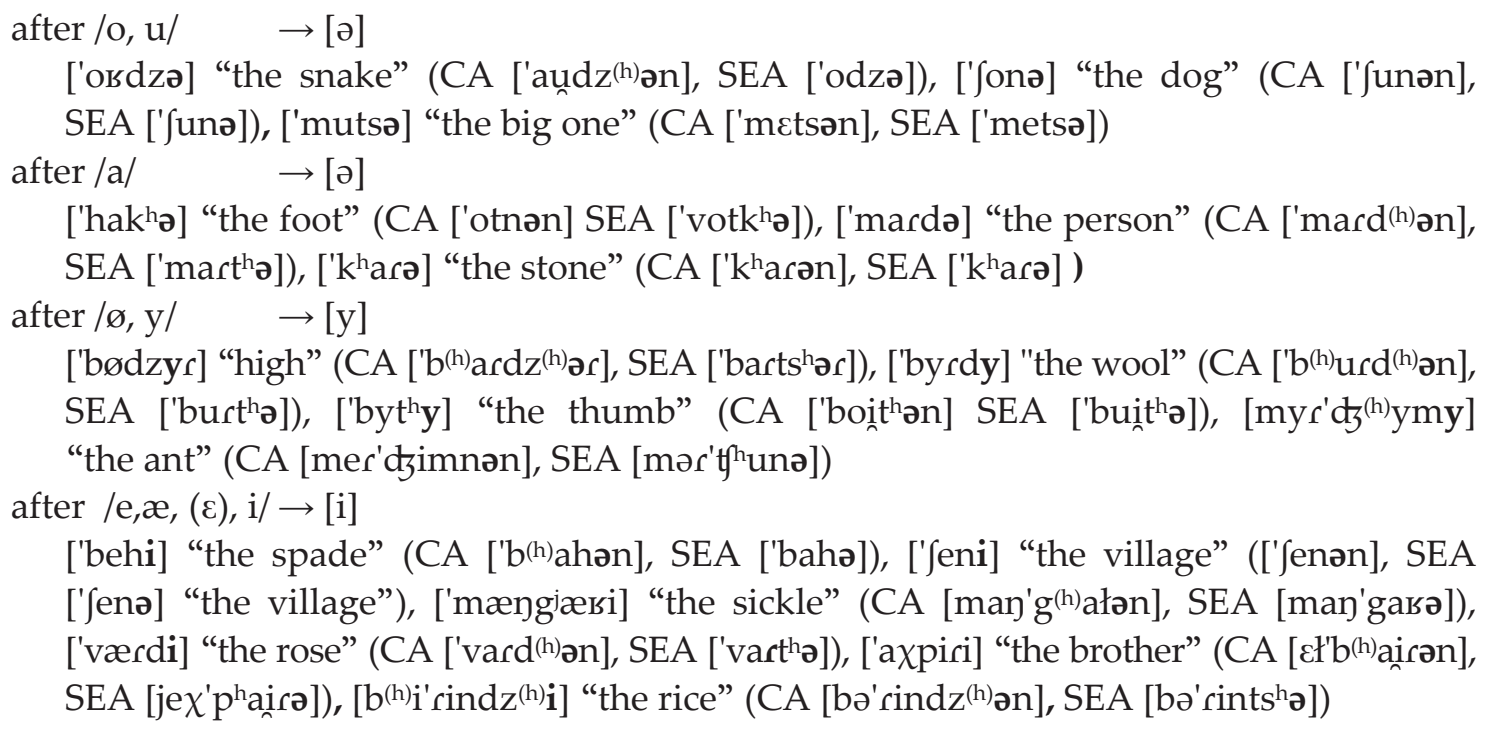

['hak'ə] "the foot” (CA ['otnən] SEA ['votk'ə]), ['mardə] "the person” (CA ['mard(h)ən], SEA ['masthə]), ['kharə] “the stone” (CA ['kharən], SEA ['kharə] )

['bødzys] "high" (CA ['b(h)ardz(h) ər], SEA ['bartsh $\boldsymbol{\partial r}$ ]), ['byrdy] "the wool" (CA ['b(h)urd(h)ən],

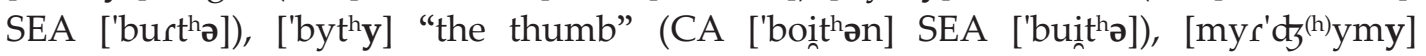
"the ant" (CA [mer'dzimnon], SEA [mər'th'unə])

['behi] "the spade” (CA ['b(h)ahən], SEA ['bahə]), ['feni] "the village” (['Jenən], SEA ['fenə] "the village”), ['mængiæi] “the sickle” (CA [man'g(h)ałən], SEA [man'gaьə]), ['værdi] "the rose" (CA ['vard(h)ən], SEA ['varthə]), ['axpiri] "the brother" (CA [et'b(h)aircən],

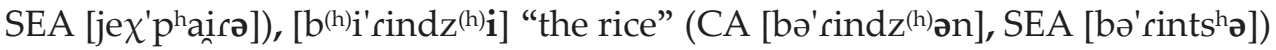

The case is interesting, because the vowel harmony of Karchevan's dialect does not fully correspond to that of Azerbaijanian from which however it has been imported.

The Azerbaijanian model shows a rigid distribution of vowels in which after $/ \mathrm{o} / \mathrm{and} / \mathrm{u} /$ the epenthetic vowel surfaces as $[\mathrm{u}]$; this regularity is not present in the dialect of Karchevan, although the phonemic inventory of this dialect includes a surface phonic unit [u]. If the borrowing of vowel harmony rule were based on the imitation of the vowel sequences admitted in the surface units of the model language, without any relation with the underlying phonological processes, this difference would be impossible to explain.

There are two remarkable facts: the dialect of Karchevan presents in its phonemic inventory a phonological unit which surfaces as $[\mathrm{u}]$ and which is identical to the Azerbaijanian model. However this unit does not surface as outcome of vowel harmony after $/ \mathrm{o} /$ and $/ \mathrm{u} /$. Moreover after /a/ we find the epenthetic vowel [ə], a vowel devoid of phonological value, and consequently not involved in vowel harmony. 
The hypothesis I would like to purpose is that, in a perspective of deep and pervasive bilingualism, the borrowing of vowel harmony does not depend on the phonetic units of the donor language and of the recipient language, but on the phonological features which are active in the rule and in the phonemic inventories. The rule has not been transferred from Azerbaijanian to Karchevan's dialect through loanwords, that is it has not been extrapolated from Azerbaijanian lexical borrowings, but it may have been imported in the Armenian dialect of Karchevan in its combinatory form, based on features and not on units. An autosegmental representation of vowel harmony in the dialect of Karchevan is given in table 6:

Table 6. Epenthetic vowel harmony in Karchevan's dialect
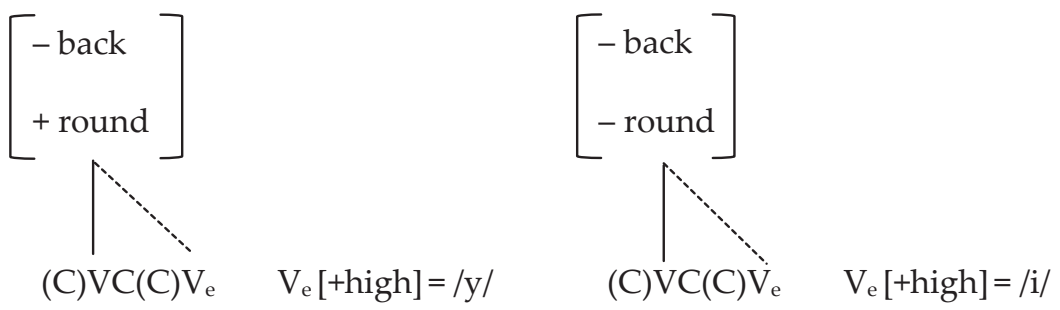

Outcomes of epenthetic vowel harmony in Karchevan are pre-specified for the feature [+high]. The only feature which is transferred to the harmonic vowels is the value [ $\alpha$ round] in the domain [-back]. Only front vowels take part into the harmony.

In this framework, the most relevant facts are that back vowels do not trigger harmonic processes and that there is no trace of an output [u] after $/ \mathrm{o} /$ and $/ \mathrm{u} /$. In these differences between the dialect of Karchevan and the Azerbaijanian model, a crucial role is played by the absence of a central vowel such as /i/ or /ə/ (in terms of harmony a vowel [+back] [+high] [-round]) in the phonemic inventory of the dialect of Karchevan. The back vowel series lacks a unit having the features [+ high] [- round] and consequently the only vowel [+back] [+high] is $/ \mathrm{u} /$, which in the harmony can be considered as not specified for the feature [round]. So the harmony rule assigns a default pre-specification [+high] and then a further specification [+back]; in this domain the rule should specify the value [ $\alpha$ round], but the phonological system of the dialect of Karchevan does not permit the conclusion of the process with the specification of the value [round], because the only one vowel [+high] and [+back] does not participate to a system of phonological oppositions implying the specification of the value [ $\alpha$ round]. Probably, as a result of this, the whole class of back vowels is excluded from harmony.

In this perspective, epenthetic vowel harmony in the dialect of Karchevan would be the outcome of the borrowing of a Turkic rule, a rule which operates as selection of features and not as selection of units. The phonological system of the recipient language, for its different configuration, especially for the lack of a phonological unit combining the features [+back] [+high] [-round], produces an output which is different from that of the model, though applying the same rule.

\subsection{Akanie in Belarus Yiddish}

A third example of phonological rule borrowing can be found in Yiddish as spoken in Belarus. The data available in the bibliography about this case are very exiguous, nevertheless it deserves at least a hint for its clarity: according to Uriel Weinreich Belarus Yiddish presents a rule according to which etymological /o/ surfaces as [a] in pre-tonic syllable (Weinreich 1958: 
371-377; cfr. also Reershemius 2007: 247-248). The rule, traditionally called akanie, is clearly of Slavic origin and it is well rooted in Belarus and in Russian (Cantarini 1979: 188-192; for Russian cfr. e.g. Jones-Ward 1969: 50-52). Belarus akanie is strongly impacting on phonological distribution of the sounds, implying the neutralization of /o/, /a/ (and /e/ as well; in this case the rule is called jakanie) in unstressed syllable (Cantarini 2001: 177). This neutralization is recorded in the Belarus orthography as early as in the $15^{\text {th }}-16^{\text {th }}$ century (Alonso de la FuenteMajtczak 2015: 23). This rule of neutralization in Belarus Yiddish acts also on non-Slavic words, cfr. [xa'lile] "God forbid!" (other Yiddish dialects [xo'lile]) and [a'korft] an emphatic particle usually placed after an imperative (other dialects [o'korft]). Unfortunately Weinreich does not give further examples, but the two words discussed are already significant. The case of pre-tonic/o/ changed in [a] in Yiddish native words is conceivable only as a result of a contextual dephonologization via contact, induced by the borrowing of a Slavic phono-prosodic rule. Pre-tonic /o/ has resisted for centuries in the Yiddish dialects and it is probable that only a new rule, acting on the phonemic underlying features, can have changed it. In this case too, the role of the loanwords seems to be not very relevant, because pre-tonic [a] was already present in Yiddish and therefore Slavic loanwords having [a] in this position could not produce a process of neutralization. The fact that Slavic loanwords in Yiddish do not show [o] in pretonic position would not be enough to modify the pronounciation of every pre-tonic /o/ in etymologically non Slavic words. Only the imitation of a phonological rule can explain this phonological innovation and the model for such an innovation is clearly available in Belarus phonology, but not in the surface representation of the Belarus lexicon.

\subsection{Phonological rule borrowing: external and internal dimensions}

All the afore-mentioned phonological rules are the result of a process of innovation in the languages they affect and have been imported from co-territorial languages in a contest of long and deep bilingualism. Phonological rule borrowing, such as that observed in Abruzzian Romani, in the Armenian dialect of Karchevan and in Belarus Yiddish, seems more likely when the lexicon of the two languages present in the repertoire of a community is totally different and when the social power and the social meaning of the two languages in contact are strongly divergent. Some other similar cases, such as Albanian dialects (Arbëresh) in Southern Italy (Savoia 2008: 43-46) and Romani of Finland (Scala in press), seem to confirm this trend. If a bilingual community entrusts a strong role of identity-marker to a language, from a cognitive point of view, the lexicon represents the most salient and accessible way of marking distance and of highlighting a different identity. If the lexicon of the intra-communitarian language is radically different to that of the inter-communitarian one, the phonology of the two languages can more easily undergo unification, by extending the model of the intercommunitarian language to both languages. On the contrary, when in a bilingual community the intra-communitarian and the inter-communitarian languages share a very similar lexicon, each phonetic detail which differentiates the two languages is carefully preserved and respected in the pronunciation; this situation is clearly observable in a lot of small communities in Italy, where the local Italo-Romance dialect, which is perceived and preserved as the intracommunitarian code, differs from neighbouring dialects or from the koine-dialect only by virtue of its phonetic features.

This sociolinguistic generalization could be represented as in tables 7 and 8 . When the intra-communitarian language is strongly identitarian and the lexicon of the two languages is very different, then phonological rules can converge (table 7). 
Table 7. When the lexicon is different, phonological rules tend to converge

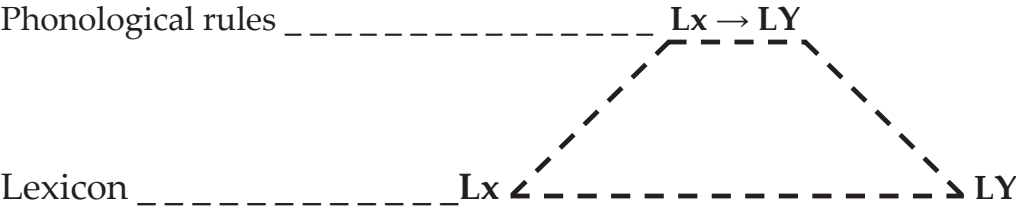

(legenda: Lx = minority intra-communitarian language, LY = co-territorial language of the majority community)

On the contrary, if the lexicon of the two languages is very similar, phonological rules convergence is generally avoided (table 8 ):

Table 8. When the lexicon is strongly similar, phonological rules remain different

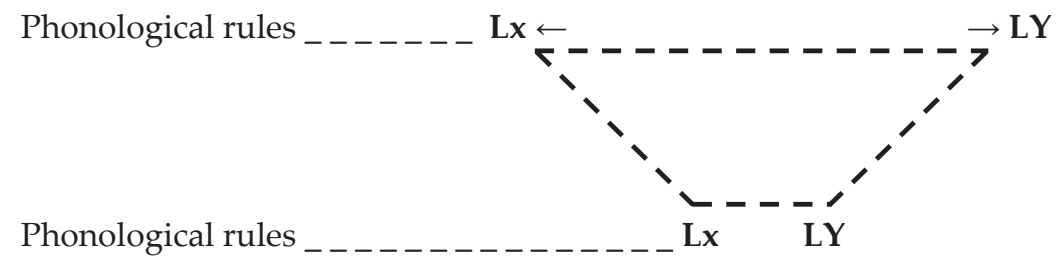

In this second case, even small phonetic details, which are often outcomes of phonological rules, remain distinct and do not tend to converge. The prerequisite of such dynamics - as said before - is that the intra-communitarian language maintains for a long time its identitarian function.

Returning to a system perspective, it has to be highlighted that in most cases the rules described above can be considered only as processes acting on phonological features and not on phonic units. The case of $/ \mathrm{u} /$ propagation is very significant: in Abruzzian Romani the phenomenon presents a set of possible target onsets that is ampler than in Abruzzese propagation, also including a phonological unit such as $/ x /$, which is unknown to the Abruzzese phonemic inventory. The phonological rule has been borrowed from Abruzzese and selects syllables whose onset has the same features as the model, but in Abruzzian Romani, because of the difference between the two phonemic inventories, it captures more units. This evidence actually seems to minimize, if not exclude, the role of the borrowed lexicon in the process of rule imitation. Also the rule which produces devoicing of /d/ after stressed vowel in Abruzzian Romani is very meaningful and cannot have been induced through lexical loanwords. The output of this rule in Abruzzese is a sequence of sounds well known to Abruzzian Romani, which in its traditional lexicon presented many cases of etymological /V́t/. Such sequence, generated in Abruzzese by an allophonic process, could have been integrated into Abruzzian Romani without any difficulty, but also without inducing any new phonological rule. On the whole, the role of the Abruzzese lexical loanwords as a vehicle for the borrowing of phonological rules into Abruzzian Romani does not seem to be particularly relevant. In fact loanwords seem to act as vehicles for new phonemes (Gusmani 1982; Stolz 2008: 21), rather than as inductors of new phonological rules, with the exception perhaps of stress patterns (Thomason 2006: 671). In Abruzzian Romani it is hard to find a phonological rule which is not shared with Abruzzese. In this perspective it may be assumed that Abruzzian Romani speakers, who have all been bilingual with Abruzzese for centuries, currently manage a set of phonological rules which serves two different languages and is applied to two different phonemic and lexical inventories.

The case of the epenthetic vowel in the Armenian dialect of Karchevan can be considered in the same light. The idea that vowel harmony has been borrowed via lexicon presents the 
crucial difficulty that after /o/ and /u/ epenthetic vowel harmony regularly occurs in Azerbaijanian, but not in Karchevan's dialect. Surface vowel inventories are identical, but underlying phonemic inventories are different and that changes the output of the harmony. In this case too, a rule borrowing based on combination of features and not on the surface units of the lexicon is the only viable hypothesis.

Finally, also the Belarus Yiddish phono-prosodic rule which produces a neutralization of /o/ and /a/ in pre-tonic position, seems to represent a further case of phonological rule that cannot have been imported via lexical borrowings, being the pre-tonic [a] already existing in Yiddish.

As said at the beginning of this article, phonological rules borrowing outside the domain of language learning has been so far a relatively unexplored topic in historical linguistics. Consequently the case-studies and the general reflections presented in this paper represent only a first attempt to define the inner (structural) and external (sociolinguistic) dynamics which enable the borrowing of phonological rules in native languages. A process of innovation in which the acquiring of loanwords does not appear to be such a relevant precondition as the contact between two different phonological competences co-existing in the same bilingual speakers.

\section{References}

Alonso de la Fuente, José Andrés, Tomasz Majtczak. 2015. A dialogue about the etymology of Yiddish páze. In: E. Mańczak-Wohlferd, B. Podolak (eds.). Words and Dictionaries. A Festschrift for Professor Stanistaw Stachowksi on the Occasion of His 85 th Birthday: 11-28. Kraków: Jagiellonian University Press.

Ačaryan, Hrač'ya. 2003. K'nnowt'yown Kilikiayi barbar̈i. Erevan: Erevani Hamalsarani Hratarakč'owt'yown. [1st edition: 1948].

Adjarian, Hratchia. 1929. Classification des dialectes arméniens. Paris: Librairie Honoré Champion.

Alekseev, Mikhail E. 1994. Budukh. In: R. Smeets (ed.). The Indigenous Languages of the Caucasus, Vol. 4: $259-296$. Delmar: Caravan Book.

Bigalke, Rainer. 1996. Abruzzese. München-Newcastle: Lincom Europa.

Bournoutian, George. 1996. The Ethnic Composition and the Socio-Economic Condition of Eastern Armenia in the First Half of the Nineteenth Century. In: R. G. Suny (ed.). Transcaucasia, Nationalism, and Social Change: 69-86. Ann Arbor: The University of Michigan Press.

Campbell, Lyle. 1976. Language contact and sound change. In: W. M. Christie (ed.). Current Progress in Historical Linguistics: Proceedings of the Second International Conference on Historical Linguistics: 111-194. Amsterdam: North Holland.

Campbell, Lyle. 1998. Historical Linguistics. Edinburgh University Press.

Cantarini, Aldo. 1979. Lineamenti di fonologia slava. Brescia: Editrice La Scuola.

Cantarini, Aldo. 2001. Le lingue slave. In: E. Banfi (ed.). La formazione dell'Europa linguistica, 2nd ed.: 145-193. Firenze: La Nuova Italia.

Dawkins, Richard M. 1916. Modern Greek in Asia Minor. Cambridge University Press.

Galustean, Grigor. 1934. Maraš kam Germanik. New York: Koč‘nak Press.

Giammarco, Ernesto. 1960. Grammatica delle parlate d'Abruzzo e Molise. Pescara: Istituto Artigianelli Abruzzesi.

Giammarco, Ernesto. 1979. Abruzzo. Pisa: Pacini.

Gusmani, Roberto. 1982. Interferenza e integrazione fonologica. Incontri Linguistici 7: 99-108.

Householder, Fred W., Mansour Lotfi. 1965. Basic course in Azerbaijani. The Hague: Indiana University Press.

Johanson, Lars. 2006. On the Role of Turkic in the Caucasus Area. In: Y. Matras, A. McMahon, N. Vincent (eds.). Linguistic Areas. Convergence in Historical and Typological Perspective: 160-181. Houndmills / Basingstoke: Palgrave Macmillan.

Jones, Daniel, Dennis Ward. 1969. The Phonetics of Russian. Cambridge University Press.

Khalilzadeh, Amir. 2013. Vowel harmony: A comparative study of Turkey's and Azerbaijani Turkish. Procedia. Social and Behavioral Sciences 70: 929-935. 
Kibrik, Aleksandr E. 1994. Khinalug. In: R. Smeets (ed.). The Indigenous Languages of the Caucasus. Vol. 4: $367-406$. Delmar: Caravan Book.

Łaribyan, Ararat. 1953. Hay barbaragitowt'yown. Erevan: Haykakan SSRं Petakan Heraka Mankavaržakan Institowti tparan.

Matras, Yaron. 2005. The classification of Romani dialects: a geographic-historical perspective. In: B. Schrammel, D. Halwachs (eds.). General and applied Romani linguistics: 7-26. Munich: Lincom Europa.

Matras, Yaron. 2009. Language Contact. Cambridge University Press.

Morelli, Bruno, Giulio Soravia. 1998. I pativ mengr. La lingua e le tradizioni dei rom abruzzesi. Roma: Centro Studi Zingari.

Mowradyan, Hovhannes. 1960. Karčevani barbaṙo. Erevan: Haykakan SSH Gitowt'yownneri Akademiayi Hratarakč'owt'yown.

Pellis, Ugo. 1936. Il rilievo zingaresco a L'Annunziata di Giulianova (Teramo). Bollettino dell'Atlante Linguistico Italiano 2(2): 61-85.

Reershemius, Gertrud. 2007. Grammatical Borrowing in Yiddish. In: Y. Matras, J. Sakel (eds.). Grammatical Borrowing in Cross-Linguistic Perspective: 244-259. Berlin / New York: Mouton de Gruyter.

Rizzi, Luigi, Leonardo Savoia. 1993. Conditions on /u/ propagation in southern Italian dialects: a locality parameter for phonosyntactic processes. In: A. Belletti (ed.). Syntactic Theory and the Dialects of Italy: 252-318. Torino: Rosenberg \& Sellier.

Rohlfs, Gerhard. 1966-1969. Grammatica storica della lingua italiana e dei suoi dialetti. 3 voll. Torino: Einaudi.

Romani Morpho-Syntax Database. Online resource: http://romani.humanities.manchester.ac.uk/rms/.

Saadiev, Sh. M. 1994. Kryts. In R. Smeets (ed.). The Indigenous Languages of the Caucasus, Vol. 4: 409-446. Delmar: Caravan Book.

Savoia, Leonardo M. 1987. Teoria generativa, modelli fonologici e dialettologia. La propagazione di u in una varietà lucana. Rivista Italiana di Dialettologia 11: 185-263.

Savoia, Leonardo M. 2008. Studi sulle varietà arbëreshe. Cosenza: Università della Calabria-Dipartimento di Linguistica (Sezione di Albanologia).

Savoia, Leonardo M. 2014. Introduzione alla fonetica e alla fonologia. Bologna: Zanichelli.

Savoia, Leonardo M. 2015. I dialetti italiani. Sistemi e processi fonologici nelle varietà di area italiana e romancia. Ospedaletto / Pisa: Pacini.

Scala, Andrea. 2006-2007. Contributi alla conoscenza dei prestiti lessicali greci nei dialetti degli zingari dell'Italia meridionale di antico insediamento. Atti del Sodalizio Glottologico Milanese, n.s. 1-2: 46-52.

Scala, Andrea. 2015. Propagginazione e romaní d'Abruzzo: un caso di importazione di regola fonologica. L'Italia dialettale 76: 181-209.

Scala, Andrea. 2018. Italo-Romance Phonological Rules and Indo-Aryan Lexicon: the case of Abruzzian Romani. In: R. D’Alessandro, D. Pescarini (eds.). Advances in Italian Dialectology: 165-187. Leiden: Brill.

Scala, Andrea. in press. L'interferenza fonologica in Jakobson e oltre. In: M. Castagneto, E. Esposito, S. Sini (eds.). Atti del Convegno "Roman Jakobson: Linguistics and Poetics”. Milano: Ledizioni.

Schirru, Giancarlo. 2008. Propagginazione e categorie nominali in un dialetto del Molise. In: A. De Angelis, Alessandro (ed.). I dialetti meridionali tra arcaismo e interferenza: 291-309. Palermo: Centro Studi Filologici e Linguistici Siciliani.

Schirru, Giancarlo. 2012-2013. Propagginazione e flessione nominale in alcuni dialetti italiani centro-meridionali. Atti del Sodalizio Glottologico Milanese, n.s. 8-9: 121-130.

Soravia, Giulio. 1978. Schizzo tagmemico del dialetto degli Zingari di Reggio Calabria. Lacio drom 14(2-3): 1-69.

Soravia, Giulio. 2009. Rom e Sinti in Italia. Breve storia della lingua e delle tradizioni. Ospedaletto / Pisa: Pacini.

Stolz, Thomas. 2008. Romancisation world-wide. In: Th. Stolz, D. Bakker and R. Salas Palomo (eds.). Aspects of Language Contact. New Theoretical, Methodological and Empirical Findings with Special Focus on Romancisation Processes: 1-42. Berlin: Mouton de Gruyter.

Thomason, Sarah, Terrence Kaufman. 1988. Language Contact, Creolization, and Genetic Linguistics. Berkley / Los Angeles / Oxford: University of California Press.

Thomason, Sarah. 2001. Language Contact. An Introduction. Washington: Georgetown University Press.

Thomason, Sarah. 2006. Rule Borrowing. In: K. Brown (ed.). Encyclopedia of Language and Linguistics, Vol. 10: 671-677. Oxford: Elsevier.

Turchetta, Barbara. 2008. Le lingue in Africa nera. In: E. Banfi, N. Grandi (eds.). Le lingue del mondo. Asia, Africa: 489-553. Roma: Carocci. 
Tuttle, Edward. 1985. Assimilazione «permansiva» negli esiti centro-meridionali di A tonica. L'Italia Dialettale 98: 1-34.

Vaux, Bert. 1998. The phonology of Armenian. Oxford: Clarendon Press.

Weinreich, Uriel. 1958. Yiddish and Colonial German in Eastern Europe. In: American Contributions to the Fourth International Congress of Slavistic, Moscow, September 1958: 369-419. The Hague: Mouton.

Yar-Shater, Eshan. 1969. A grammar of southern Tati dialects. The Hague / Paris: Mouton.

Андреа Скала. Заимствование фонологических правил: общие соображения и конкретные исследования (на примере цыганского, армянского и идиш)

Проблема заимствований фонологических правил в научных исследованиях в основном ограничена областью языкового обучения. При этом воспроизведение фонологических правил языка 1 в высказываниях на языке 2 - довольно обыденное явление; намного интереснее случаи, когда заимствование фонологических правил приводит к перестройке синтагматической фонологии хорошо сохранившегося малого языка. В таких случаях мы наблюдаем, как язык внутреннего общения конкретного этнического меньшинства частично или полностью перенимает фонологические правила, характерные для языка внешнего общения (т. е. языка национального большинства). В данной статье исследуется ряд примеров таких заимствований, включая два италороманских фонологических правила, заимствованных в цыганский язык области Абруццо; сингармонизм тюркского типа в карчеванском диалекте армянского и белорусское аканье в белорусском идиш. Анализ правил и возможных путей их заимствования завершается общими рассуждениями на тему структурного и социолингвистического характера этого явления.

Ключевые слова: фонологические правила, языковые заимствования, цыганский язык, армянский язык, идиш, языковые контакты 